\title{
WEAKENED SOCIAL NETWORK: THE EXPERIENCE OF CAREGIVERS OF THE HIV-EXPOSED INFANT ${ }^{1}$
}

\author{
Willyane de Andrade Alvarenga², Marli Teresinha Gimeniz Galvão3, Lucila Castanheira Nascimento , Maria \\ Isabel Ruiz Beretta ${ }^{5}$, Giselle Dupas ${ }^{6}$
}
${ }^{1}$ This text is part of the thesis - Taking care of children exposed to the human immunodeficiency virus: an interpretation in the light of Symbolic Interactionism, presented to the Programa de Pós-Graduação em Enfermagem at Universidade Federal de São Carlos (UFSCar), 2014. Funding from Fundação de Amparo à Pesquisa do Estado de São Paulo.
2 Ph.D. student in Nursing, Programa de Saúde Pública, Escola de Enfermagem de Ribeirão Preto (EERP), Universidade de São Paulo (USP). Ribeirão Preto, São Paulo, Brazil. E-mail: willyalvarenga@hotmail.com
${ }^{3}$ Ph.D. in Nursing. Associate Professor, Departamento de Enfermagem at Universidade Federal do Ceará. Fortaleza, Ceará, Brazil. E-mail: marligalvao@gmail.com
${ }^{4}$ Ph.D. in Nursing. Associate Professor, Departamento de Enfermagem Materno-Infantil e Saúde Pública at EERP/USP. Ribeirão- Preto, São Paulo, Brazil. E-mail: lucila@eerp.usp.br
${ }^{5}$ Ph.D. in Nursing. Associate Professor, Departamento de Enfermagem at UFSCar. São Carlos, São Paulo, Brazil. E-mail: dmirb@ ufscar.br
${ }^{6}$ Ph.D. in Nursing. Associate Professor, Departamento de Enfermagem at UFSCar. São Carlos, São Paulo, Brazil. E-mail: gdupas@ ufscar.br

\begin{abstract}
This study aimed to know the social network and social support the caregiver had available to take care of children exposed to HIV in the postnatal period. It is a descriptive study with a qualitative approach that used the theoretical framework of Symbolic Interactionism. Data were collected through interviews with 36 caregivers of children born to HIV-infected mothers who were followed up in a specialized service in the Northeast of Brazil and they were analyzed by inductive content analysis. The results revealed three categories that show the family and expert service as the main social networks of the caregiver and little emotional, information, instrumental and appreciation support received both in the family and in the context of health services. Interventions are needed to strengthen the weakened social network of the caregiver and to qualify and include nursing care in the context of children exposed to HIV.
\end{abstract}

DESCRIPTORS: HIV. Social support. Caregivers. Child. Nursing.

\section{REDE SOCIAL FRAGILIZADA: A EXPERIÊNCIA DO CUIDADOR DA CRIANÇA NASCIDA EXPOSTA AO HIV}

\begin{abstract}
RESUMO: Este estudo objetivou conhecer a rede social e o apoio social que o cuidador dispôs para cuidar da criança exposta ao HIV, no período pós-natal. É um estudo descritivo, com abordagem qualitativa, que utilizou como referencial teórico o Interacionismo Simbólico. Os dados foram coletados por meio de entrevista com 36 cuidadores de crianças nascidas de mães infectadas pelo HIV, que estavam em seguimento em um serviço especializado no Nordeste do Brasil, e foram analisados pela Análise de Conteúdo indutiva. Os resultados revelaram três categorias que evidenciam a família e o serviço especializado como as principais redes sociais do cuidador e o pouco apoio emocional, informativo, instrumental e de apreciação recebidos tanto no âmbito familiar quanto no contexto dos serviços de saúde. Intervenções são necessárias para fortalecer a rede social fragilizada do cuidador e para qualificar e efetivar a inserção da enfermagem neste contexto de cuidado à criança exposta ao HIV.
\end{abstract}

DESCRITORES: HIV. Apoio social. Cuidadores. Criança. Enfermagem.

\section{RED SOCIAL DEBILITADA: LA EXPERIENCIA DE LOS CUIDADORES DE LOS NIÑOS EXPUESTOS AL VIH}

RESUMEN: Este estudio tuvo como objetivo conocer la red social y el apoyo social que el cuidador tenía disponibles para cuidar de los niños expuestos al VIH en el periodo postnatal. Se trata de un estudio descriptivo con abordaje cualitativo que utilizó la perspectiva teórica del Interaccionsimo Simbólico. Los datos fueron recolectados a través de entrevistas con 36 cuidadores de los niños nacidos de madres infectadas por el VIH con seguimiento en un servicio especializado en el nordeste de Brasil y fueron analizados por análisis de contenido inductivo. Los resultados revelaron tres categorías que muestran la familia y el servicio especializado como las principales redes sociales del cuidador y el poco apoyo emocional, información, instrumental y aprecio recibidas tanto en la familia y en el contexto de los servicios de salud. Se requieren intervenciones para fortalecer la red social debilitada del cuidador y de calificar y efectuar la inserción de los cuidados de enfermería en este contexto que el niño expuesto al VIH.

DESCRIPTORES: VIH. Apoyo social. Cuidadores. Niño. Enfermería. 


\section{INTRODUCTION}

The heterosexualization of the human immunodeficiency virus (HIV) epidemic led to an increase in the number of infection cases among women and, consequently, to the birth of children exposed to the virus due to vertical transmission. Prophylactic measures to prevent this transmission were implemented in the Brazilian Unified Health System (SUS). ${ }^{1}$ The recommendations for care due to HIV included rapid testing in parturient women, provision of antiretroviral therapy (ART) for women living with HIV and their infants, appropriate management of delivery and birth, inhibition of breastfeeding and provision of infant milk formula, case reporting and monitoring of puerperal woman and exposed infant until the child's serum status has been defined. ${ }^{2}$

Globally, the number of cases of the disease in children has dropped in recent years, due to the access to ART among pregnant women living with HIV. Access to prevention and treatment services is not a reality in all countries though, mainly in developing countries. ${ }^{3}$ Besides the presence of HIV, which interferes in the relationship network, the mother takes different kinds of care, since pregnancy, to protect the child, which relates to the need to receive emotional and social support. ${ }^{4}$

Support from the Specialized Care Service (SCS) in HIV/AIDS is very important for the mother's acceptance and for a better experience of the care period to children exposed to HIV. ${ }^{5}$ Besides establishing a bond with this service, some caregivers also use other networks and support, such as the church and family, to better cope with the disease. ${ }^{5-6}$

The social network refers to the structural or institutional dimension of the individual, such as the religious organizations, the family and the health services. Social support has an individual dimension, which comprises the members of the social network the person considers important. There are four classes of social support: appreciation support, which refers to the expressions and feelings of affirmation and feedback; emotional support, related to affection, esteem and concern; informative support, related to the suggestions, information and advice; and instrumental support, which refers to the labor or financial aid and to how long they dedicate themselves. ${ }^{7}$
In this situation, the networks and the different kinds of support are needed, as the discovery of the infection can result in distancing from and approximation to loved ones, due to their assumption of a prejudiced and discriminatory attitude..$^{8-9}$ Growing levels of stigma are associated with low levels of adherence to ART, and factors like social support and strategies to cope with the stigma can positively influence this adherence. ${ }^{10}$

The mothers and caregivers go through conflicts that increase the level of anxiety and fear, due to the possibility of transmitting HIV to the child. ${ }^{4}$ The fear of the stigma, ${ }^{6}$ the insecurity and the feeling of threat the disease causes interfere in care for the child, considering that, after the discharge from the maternity hospital, the mother will still assume several responsibilities towards the child, related to medication therapy and the replacement of breastfeeding for example. ${ }^{11}$ Therefore, the health professionals need to offer information and welcoming. ${ }^{5}$ Hence, this research aimed to get to know the social network and social support the caregivers had at their disposal to take care of children exposed to HIV at birth in the postnatal period.

\section{METHOD}

A descriptive qualitative approach and Symbolic Interactionism were used as the theoretical framework to apprehend the meanings and the composition of the interactions that reflect in the support experience. ${ }^{12}$

The scenario was a public health institution that is considered a specialized referral institution for care delivery to people living with HIV/ Aids (PLHA) in a State in the Northeast of Brazil. The study participants were 36 caregivers of children born to mothers infected with HIV. The study selection criteria were, being a caregiver to a child exposed to HIV in the age range until 18 months, who was followed at the specialized service. Caregivers were defined as the people who participated actively in the care process to the exposed child, independently of blood relations, and who knew the child's condition of vertical exposure to HIV.

The participants were contacted in the waiting room of the consultation rooms and invited into a private room the service had offered for this purpose, where they were informed about the research and invited to participate. After the 
Informed Consent Form had been signed, a single interviewer held semistructured interviews during single meetings. When the caregiver was alone, the interview was held individually and, when a companion was present who also took care of the child, that person was invited to participate and a combined interview was held.

The reports were audiorecorded and some triggering questions were asked, such as: "Who has helped you to take care of the child? What institutions do you or have you attended with the child? How would you describe your relations with the people, family members and employees (at the institution mentioned)? How have you (caregiver and child) been received at the specialized service, who forwarded you and what has the care provided been like?".

The interviews took 50 minutes on average and were fully transcribed. In addition, a field diary was used to support the data collection, which took place between December 2012 and February 2013. The number of participants was limited by the theoretical saturation of the data, when no new reflections on the theme appeared and the data became repetitive. ${ }^{13}$ Two mothers refused to participate, one due to a lack of time and the other due to a lack of emotional conditions, as she had discovered her serum status on the same day.

Inductive content analysis was used to analyze the data, considering that this method has been commonly used in nursing research for qualitative approaches. ${ }^{14}$ It consists of three phases: preparation, organization and reporting of the results. ${ }^{15}$ The first step in the analysis was the preparation phase, that is, after the full transcription of the interviews and repeated readings to obtain the meaning of everything, the units of meaning were identified, which refer to words, phrases or paragraphs related to the research problem and context under investigation, guided by the research objective and theoretical framework. In the organization phase, the inductive route was chosen, in which the interpretation process of subjective data analysis took place, including common aspects, relations and differences among them, coding them and integrating them in categories, and then grouping the data to reduce the number of categories. Thus, a general description of the research phenomenon was formulated through the elaboration and abstraction of the categories. In the final phase, the results from the previous phase were reported through the organization and chronological presentation of the categories, starting from birth, emphasizing the study participants' social networks and social support.

To present the results, the identification resource of the participants' discourse was adopted, based on the description of the caregiver's family position in relation to the child (father, mother), following by the number that identifies each child. This format to distinguish the interviewees was aimed at preserving the investigated participants' identity, whose participation complied with the ethical standards for research involving human beings in force at that time. Approval for the study was obtained from the Institutional Review Board of Universidade Federal de São Carlos (n. 112.500/2012).

\section{RESULTS}

Thirty-six participants were interviewed, who were relatives of 29 children exposed to HIV (one twin), who were monitored at the specialized service. The interviewees included mothers living with HIV $(n=23)$, fathers $(n=5)$, aunts $(n=2)$, grand parents $(n=4)$, great-grandmother $(n=1)$ and foster mother $(n=1)$, some of whom served as the main caregiver $(n=8)$ and were blood-related to the child or not.

Table 1 displays the main caregivers' general characteristics and the clinical characteristics of the biological mothers to the children exposed to HIV, who were attended at the place of study. Most of the main caregivers $(n=23 ; 82.14 \%)$ were mothers living with HIV, but other people, like the grandmother, great-grandmother, aunt or foster mothers took up that role due to the absence of the biological mother, due to death, abandonment or adoption, or when the child lived with the father or grandmother. Most main caregivers were between 20 and 30 years of age $(n=15$; $53.57 \%)$; as regards education, most had finished primary $(n=12 ; 42.86 \%)$ or secondary education $(n=12 ; 42.86 \%)$ and the most frequent marital situation was married and/or with a fixed partner $(n=16 ; 57.14 \%)$. Most mothers discovered the HIV diagnosis during pregnancy $(n=14 ; 50 \%)$, received prenatal monitoring $(\mathrm{n}=25 ; 89.29 \%)$ and used ART (Zidovudine - AZT) during pregnancy $(\mathrm{n}=24 ; 85.72 \%)$. 
Table 1 - General characteristics of caregivers and clinical characteristics of the biological mothers to the children exposed to HIV who were attended at a specialized service. Northeastern city, Brazil, December/2012 till February/2013

\begin{tabular}{|c|c|c|}
\hline Variables & $\mathbf{n}$ & $\%$ \\
\hline \multicolumn{3}{|l|}{ Primary caregiver } \\
\hline Mother living with $\mathrm{HIV}^{*}$ & 23 & 82.14 \\
\hline Other & 5 & 17.86 \\
\hline \multicolumn{3}{|l|}{ Age (years) } \\
\hline $20-30$ & 15 & 53.57 \\
\hline$\geq 31$ & 13 & 46.43 \\
\hline \multicolumn{3}{|l|}{ Education } \\
\hline No education & 2 & 7.14 \\
\hline Primary education & 12 & 42.86 \\
\hline Secondary education & 12 & 42.86 \\
\hline Higher education & 2 & 7.14 \\
\hline \multicolumn{3}{|l|}{ Marital situation } \\
\hline Married/fixed partner & 16 & 57.14 \\
\hline Single & 8 & 28.57 \\
\hline Widowed & 4 & 14.29 \\
\hline \multicolumn{3}{|c|}{$\begin{array}{l}\text { Discovery of the HIV diagnosis by the } \\
\text { mother }\end{array}$} \\
\hline During pregnancy & 14 & 50.00 \\
\hline Before pregnancy & 8 & 28.57 \\
\hline Post-partum & 4 & 14.29 \\
\hline During birth & 2 & 7.14 \\
\hline \multicolumn{3}{|l|}{ Prenatal care† } \\
\hline Yes & 25 & 89.29 \\
\hline No & 2 & 7.14 \\
\hline Does not know & 1 & 3.57 \\
\hline \multicolumn{3}{|c|}{$\begin{array}{l}\text { Use of antiretroviral therapy during preg- } \\
\text { nancy } \dagger\end{array}$} \\
\hline Yes & 24 & 85.72 \\
\hline No & 2 & 7.14 \\
\hline Does not know & 2 & 7.14 \\
\hline
\end{tabular}

The data analysis permitted the identification of three categories: 1) Disintegration of the social network for the follow-up of the child; 2) Trust and mistrust: relation with SCS and other health services; and 3) Social support in weakened social network.

\section{Disintegration of social network for the follow-up of the child}

Before the birth of the child, the mothers' social network was the health service where she received prenatal care and the SCS, as most mothers in this study received prenatal care and took ART during pregnancy. The health profes- sionals who interacted with the mothers during pregnancy did not establish the bond of who would serve as the child's main caregiver with other networks for the construction of an integration social network. When the child was born, the caregiver's main social network was the maternity hospital and this network was disintegrated after the child's discharge. The health professionals at the maternity hospital advised the caregiver to attend the SCS only for the follow-up of the child and this service turned into the main social network. Nevertheless, difficulties arose to like up with that network.

The maternity professionals' orientation to the caregiver was incomplete or not properly received, as many caregivers did not know when to attend the service or how to schedule the child's first consultation, as well as the place where the SCS attended for child follow-up. Some participants reported orientations to visit the service after 15 days, others after one month. In addition, the mother's lack of knowledge about her HIV serum status was observed, as some did not understand the need for the child to be monitored at a specialized service, which reveals the frailty in the health professionals' information support to the caregivers, impairing the child's follow-up.

She [nursing] did the rapid test and it was positive, but they did not tell me. [...] they only had me forwarded to the Hospital [headquarters of SCS] to bring the baby. They only gave me a paper and didn't tell if we had to call first to schedule the child's appointment (Mother 26).

She was forwarded from the maternity hospital to the SCS. They said she needed monitoring because of her mother's HIV and that we should come after 40 days (Grandmother 16).

The specialized service where the children in this research were monitored received them at more than one month of life, while a minority was attended younger. The children did not receive monitoring from the service early for different reasons. The delay in care created space for errors, doubts, fear and concern, which highlights the lack of information and emotional support at the institution where the child was born and at the SCS. Many mothers would like to have been attended earlier and receive support in this initial phase of the child's life.

The doctor from the maternity hospital asked us to come to the SCS after fifteen day. We came to schedule the appointment and the attendant said he [physician] did not receive children at the age of 15 days, because 
my surgery was recent and the child's belly button had not healed yet. She said I should come at the age of 30 days [...]. I would like to have been attended. I got concerned. He [father] asked whether there would be any complication if the visit happened at more than 15 days. She [attendant] said: 'No! Is he taking the medicine correctly?' (Mother 3).

\section{Trust and mistrust: relation with Special Care Servise and other health services}

The mothers prefer the SCS to other health network services to monitor the child and emphasize this institution as the main component of the social network. They believe that this service is capable of offering them instrumental support, as they receive formula milk and medication freely, emotional, information and appreciation support, due to the trust in the professionals, the discretion and specialization with which they treat PLHA, besides the fact that the service is attended by people who experience similar situations.

I thought this Hospital was our only salvation and hope. This is the only hospital that offers the treatment and gives the medicines for free (Mother 15).

There are other people with this disease here and their history is similar, they have something in common with me (Mother 8).

In addition, some people do not like to attend the service, although they consider it important for the child's monitoring. Entering the SCS reminds them of their serum status, as if the mothers got closer to the situation they would like to be able to forget. They are afraid that the service might "denounce" their serum status or the child's condition, due to the stigma associated with the SCS. Other negative points, such as infrastructure problems, care delays, inappropriate times for the routine of mothers/caregivers living in other cities and the patients' great demand during the consultations were appointed as difficulties that reveal moments of lack of support.

People are prejudiced towards this hospital because most people who are here have a contagious disease. So they know we are here because of the HIV (Mother 23).

I don' like bringing him here [...] because I know the reason. I don' tike what is being treated here, seeing other children makes me sad, it seems we get closer to the problem (Mother 20).

There is a great delay in care, because there are many children; the mothers cannot breastfeed and they need to bring the milk. Many mothers come from the interior of the State and sleep here because they lose the bus back due to the delay and they don' get any assistance (Mother 25).

Other services in the network are also used, such as the Family Health Strategy (FHS) and the emergency services, most of which were visited punctually. The fact that they did not visit or seek other services was justified by the mistrust when they revealed the serum status, mainly to the FHS professionals, due to the lack of human resources at these services and because the mother does not always consider that the child needs monitoring beyond what she already received at the SCS.

The professionals here are great [...]. The physicians are well trained. [...] The baby only comes here, I don't take here to the health service [FHS] because the pediatrician is absent a lot. If she [child] gets ill, I come here [SCS], because the doctor is a pediatrician and infectious disease specialist. The team is prepared for the problem (Mother 27).

The difficulty to get periodical monitoring for the child was present in these caregivers' daily life. The main reasons were the access between the city of origin and the city of treatment and the lack of resources and instrumental support to pay for the treatment. Nevertheless, the children in this study did attend the SCS consultations. Another difficulty mentioned was related to scheduling the appointment.

I am complying with everything. When the physician asks I schedule the appointment and come, but it's difficult. My wage is low and I need to pay the travel fee. I wish I'd get some aid because my salary is insufficient (Aunt 19).

It's very far from where I live here. The trip takes four hours (Mother 12).

It's a bit difficult with the consultations here. The doctor [FHS] makes the appointment and gives me the forwarding letter, I take that to the service [FHS], for them to make the appointment and for the SUS to authorize it, and then I come for the next consultation (Mother 25).

\section{Social support in weakened social network}

This category appoints the caregivers' social support, which is restricted to some family members, people suffering from HIV and health professionals, particularly the SCS. The stigma related to the virus weakens the relations, interfering in the supply of support to the caregiver and also in his perception to feel supported by someone. 
Most family members know the mothers' seropositive status and the child's condition; nevertheless, some people decide not to tell it out of fear of losing the support. Instrumental and emotional support was offered to the mothers in care for the child and was not equally present among the family members who know the diagnosis.

My family is not prejudiced. After I told them, they are paying more attention, showing concern. They have always been concerned, but they are more now (Mother 11).

They know [...], my uncle has never 'turned his back' on me, but my grandmother and aunt rejected me [...] (Mother 28).

The family's support is received as conditional, and the relations become mined by prejudice and by the fear and catching HIV at home. According to the mothers, when there is prejudice, there is no support, giving rise to internal conflicts in the family and distancing from family members. The lack of support causes feelings of frustration, sadness and solitude, in which the individual is isolated and isolates herself in this midst. The main source of support was the partner or the child's grandmother.

My sister, who lives with me, accepts that I have the disease, but she's afraid of the spoon or cup I use. I have my things. I don't cook because they [family] don't let me. [...]. The family is prejudiced but, at the same time, they show that there are not. I don't feel a lot of support, because [...] when there's prejudice there's no support (Mother 13).

The waiting room for the child's consultation turned into a place where the mothers exchange experiences and receive emotional, information and appreciation support. A moment of learning with people they consider "peers" and who present similar dilemmas.

It's because I listen to other people's problem. One of them tells how and when she caught HIV, these conversations give me strength. Because I know I am not the only one, that there are other people. [...] everyone talks a lot, that does not happen anywhere else (Mother 14).

During the care trajectory of the child exposed to HIV, both support and lack of support from health professionals. The professionals' support was felt by the confidence transmitted during the consultations, the hope the caregivers transmitted with regard to the negative HIV diagnosis in the child and based on shared information and orientations. These professionals were mainly affiliated with the SCS and the physicians stood out.
I am going to thank him a lot because he was a marvelous pediatrician, he always did everything he could. He gives advice, talks a lot, likes the baby and examines him. It's all perfect. I can't criticize the treatment or his monitoring as a pediatrician specialized in infectious diseases (Mother 9).

Prejudice appeared in most of the reports and, in general, related to other health services. According to the mothers, many professionals look differently at who lives with the virus, adopt discriminatory behaviors and depreciative comments that blame the mothers, which evidences the lack of emotional and appreciation support. Thus, they do not feel safe about the confidentiality of the diagnosis. The feeling of exclusion, isolation and disrespect came with tears during the interviews, mainly among mothers and fathers. Support, humanization and better care were the targets.

My family found out on the day I gave birth, because the doctors told them. I didn't want them to tell [...]. They didn't have that right [...] They were with me when they told my companion (Mother 13).

They want to blame us for something we are not guilty of, because I didn't want to catch HIV. Some [professionals] looked at me differently (Mother 16).

At the maternity hospital, there is an exclusive ward for people with HIV. [...] When she [wife] was hospitalized there were about five people in the same situation as hers. Some people arrived at the door and looked, saying "that person has HIV". I heard that! Them saying that the room is exclusively for people with $H I V$. These things demonstrate the rejection (Father 3).

\section{DISCUSSION}

Most of the women living with HIV in this study were 30 years old or less, and this profile corresponds to the reproductive age and the age range of most women living with HIV/AIDS in Brazil. ${ }^{16}$ Other studies appoint similar data regarding the age range, marital status and education level of the mothers living with HIV, who were the main caregivers in the study. ${ }^{17-18}$ Most of them received prenatal care and used AZT during pregnancy, who shows interest in and concern with treatment compliance. Nevertheless, the period when most of them discovered the HIV was during prenatal care, different from other Brazilian studies in which the women were already familiar with their serum status before the pregnancy..$^{18-19}$

The results reveal the caregivers' difficulty to get access to the specialized service for the child's follow-up, which demonstrates how the social 
network of health services is detached and how the health professionals do not provide information support after the child's discharge from the maternity hospital. The child should be discharged from the maternity hospital with an appointment at a specialized service for the follow-up of children exposed to HIV. The date of the first consultation should be between 15 and 30 days after birth. ${ }^{2}$ Not only the SCS and the maternity hospital should be highlighted in the social network of health services, but basic care plays a fundamental role and should cooperate with these networks. Primary care is important in the forwarding to the SCS, in case the maternity hospital has not provided it, in the follow-up of the child, in childcare, home visits and family orientations on how to use and get the infant formula. ${ }^{20}$

Another study showed similar results regarding the child's delay to start the follow-up at the specialized service, revealing the disconnection of the social network, frailty in social support to the caregivers and in childcare. The motives were that the service did not know about the child's condition or the lack of time for an appointment because of the demand, because the maternity hospital or primary care service did not make the first appointment and, when they did, the clients did not attend on the day scheduled. This impaired the treatment because some children who were being followed had not done the laboratory tests according to the recommendations; others, due to the delayed follow-up by the service, started the prophylaxis for pneumonia late or had not even started. ${ }^{11}$

Lack of emotional and instrumental support interfere in the treatment adherence and quality. Problems like transportation difficulties, lack of sufficient financial resources and dependence on ambulances to attend the consultations and collect material for the requested tests, which were also found in another study, ${ }^{19}$ can lead to the loss of follow-up and to childhood mortality. ${ }^{21}$ The delivery of instrumental and socioeconomic support can reduce that, as a strategy to promote the continuity of care. ${ }^{21}$ Inefficient follow-up is more due to the lack of structure of the health services and the professionals' errors than to the mother's ability to take care of the child. ${ }^{11}$

The mothers also experience life with HIV, fear of prejudice, criticism, exclusion and disbelief in the existence of social support, making them choose to omit the diagnosis. ${ }^{22-23}$ According to Symbolic Interactionism, human beings interact taking into account what the other people are doing or are about to do. Thus, they are forced to guide their own conduct or to manipulate the situation. ${ }^{12}$ Despite the mother's desire to tell the health professionals about their serum status, the fear of stigma and the dear that this revelation may turn into a barrier for care prevents that. ${ }^{6,24}$

The lack of secrecy of the diagnosis, the professionals' lack of humanization and disease management orientations are linked to these factors and, in this context, the SCS professionals were also included, ${ }^{4}$ different from our results, in which the caregivers mentioned that these professionals, particularly the physicians, provided information and even emotional support. Situations of health professionals' prejudice have been related to other health contexts and have also been picture in another qualitative study. ${ }^{25}$

The interactionist approach analyzes what happens and how people act in relation to others. Individuals are understood based on their behavior, and the meaning of everything they attribute to what they perceive is expressed in the actions and defined by the others. ${ }^{12}$ The particular meaning of living with HIV is expressed in the social relations and the interaction with the prejudice was the most evidenced in this study.

The fear of prejudice and of being identified as an individual living with HIV because of attending the specialized service is a global demand, present on different continents. In the USA, families living with HIV are followed at specialized clinics for HIV/AIDS and community organizations and prefer the services focused on HIV, but not necessary identified as such. ${ }^{26}$ In Thailand, the families prefer the primary health care services, which also provide care for HIV and, similar to what happens in the USA, the specialized HIV services make efforts not to identify the service as attending HIV patients, so as to protect the confidentiality of who lives with the virus. In South Africa, the families also indicate the preference of conventional services inside the community, such as primary care clinics or a home visit program for maternal-infant health. ${ }^{26}$

Family support is important for the mother, besides the sharing of the care for children exposed to HIV. The parents and children can be confronted with situations of prejudice, encouraged by disinformation on the transmission modes, revealing the lack of support from relatives, neighbors and friends. ${ }^{22}$ Like in another study, it was perceived that the prejudice is experienced in the community 
and in the family. ${ }^{23,25}$ In some cases, the disinformation on the infection forms is huge, provoking the separation of clothing and utensils at home out of fear of HIV transmission. ${ }^{25}$

HIV impacts and strategies to cope with the situation include the strengthening of social support to the families and the construction of networks with other families living with HIV. ${ }^{27}$ The support received by the PLHAs found in this study, in the context of the waiting room for consultations at the SCS, has also been valued in other studies ${ }^{22,25}$ that strengthen the promotion of therapeutic groups, aiming for experience exchange and mutual support among peers. ${ }^{22}$ That is an opportunity to get to know people who are considered to be in the same situation, which may grant access to expanded emotional support and the feeling of belonging to the group, avoiding isolation. Due to social acceptance, most PLHAs tend to seek emotional support from other PLHAs instead of intimate friends and relatives. ${ }^{25}$ The adoption of the other person's role and the common meanings known and acknowledged due to the HIV grant such closer interaction.

\section{CONCLUSION}

The objective in this study was reached, as the caregivers' social network and social support after the birth of the children exposed to HIV were discovered, as well as the relationship with the networks and social network members. The family and the specialized service stood out in the caregivers' social network. The disintegration of the health service networks and the frailty of the support received were evidenced, mainly due to the stigma of living with HIV and the discontinuity of childcare between the discharge from the maternity hospital and the start of follow-up at the specialized service. Little emotional, information, instrumental and appreciation support were granted to the caregivers, in the family sphere and in the context of the health services.

Humanization in care delivery to PLHAs, public policies focused on reducing the stigma of living with HIV/ Aids and the structuring of care services for children exposed to HIV are extremely necessary for care promotion to the families who live with children exposed to HIV. On this trajectory, the inclusion of nursing and the primary care service are fundamental to support and welcome the caregivers. Group activities with caregivers are a support intervention strategy that can improve the coping skills.
In this study, some limitations should be taken into account. The participants were recruited and the data were collected at the institution where the child was monitored, which could permit reports of greater satisfaction with the specialized service and support from health professionals. Other limitations could be related to the presence of another caregiver in the group interviews and to the time chosen, which was while awaiting the child's consultation. It is also acknowledged that the research results cannot be generalized, due to the number of participants and due to lack of knowledge on the experience of caregivers who attend private health services for the children's follow-up.

Future research on social networks and social support for the caregivers and family members of children exposed to HIV and their strengthening mechanisms can be developed in other contexts as well as in nursing work. Getting to know the social networks and support of caregivers to children exposed to HIV can support the supply of effective support and assess the functioning of supportive bonds.

\section{REFERENCES}

1. Ministério da Saúde (BR). Secretaria de Vigilância em Saúde. Departamento de DST, Aids e Hepatites Virais. Transmissão vertical do HIV e sífilis: estratégias para redução e eliminação. Brasília (DF): MS; 2014.

2. Ministério da Saúde (BR). Protocolo clínico e diretrizes terapêuticas para manejo da infecção pelo HIV em crianças e adolescentes. Brasília (DF): Ministério da Saúde; 2014.

3. Joint United Nations Programme on HIV/AIDS (UNAIDS). Global report: UNAIDS report on the global AIDS epidemic 2013. Geneva (SW): World Health Organization; 2013.

4. Galvão MTG, Cunha GH, Machado MMT. Dilemas e conflitos de ser mãe na vigência do HIV / Aids. Rev Bras Enferm. 2010; 63(3):371-6.

5. Faria ER, Piccinini CA. Maternidade no contexto do HIV/AIDS: gestação e terceiro mês de vida do bebê. Estud Psicol. 2010; 27(2):147-59.

6. Jerome J, Galvao MTG, Lindau ST. Brazilian mothers with HIV: experiences with diagnosis and treatment in human rights based health care system. AIDS Care. 2012 Apr; 24(4):491-5.

7. Bullock K. Family social support: conceptual frameworks for nursing practice to promote and protect health. In: Bomar PJ. Promoting health in families: applying family research and theory to nursing practice. Philadelphia (US): Saunders; 2004. p.142-61 
8. Silveira EAA, Carvalho AMP. Health care support to patients with AIDS: the convoy model and nursing. Rev Esc Enferm USP. 2011; 45(3):645-50.

9. Tsai AC, Bangsberg DR, Kegeles SM, Katz IT, Haberer JE, Muzoora C, et al. internalized stigma, social distance, and disclosure of HIV Seropositivity in rural Uganda. Ann Behav Med. 2013; 46:285-94.

10. Martinez J, Harper G, Carleton RA, Hosek S, Bojan $\mathrm{K}$, Glum $\mathrm{G}$, et al. The impact of stigma on medication adherence among HIV-positive adolescent and young adult females and the moderating effects of coping and satisfaction with health care. AIDS Patient Care STDS. 2012 Feb; 26(2):108-15.

11. Barroso LMM, Galvão MTG, Cavalcante RM; Freitas JG. Cuidado materno aos filhos nascidos expostos ao HIV/AIDS. Rev Rene. 2009; 10(4):155-64.

12. Charon JM. Symbolic Interactionism: an introduction, na interpretacion, na integration. 10th ed. Upper Saddle River (US): Prentice Hall; 2010.

13. Fontanella BJB, Magdaleno Júnior R. Saturação teórica em pesquisas qualitativas: contribuições psicanalíticas. Psicol Estud. 2012 Jan-Mar; 17(1):63-71.

14. Vaismoradi M, Turunen H, Bondas T. Content analysis and thematic analysis: Implications for conducting a qualitative descriptive study. Nurs Health Scienc. 2013 Mar; 15: 398-405.

15. Elo S, Kääriäinen M, Kanste O, Pölkki T, Utriainen $\mathrm{K}$, Kyngäs H. Qualitative content analysis: a focus on trustworthiness. SAGE Open. 2014 Feb; 4(1):1-10.

16. Ministério da Saúde (BR). Boletim epidemiológico AIDS e DST. Ano III(1). Brasília (DF): MS; 2014.

17. Teixeira LB, Pilecco FB, Vigo A, Knauth DR. Sexual and reproductive health of women living with HIV in Southern Brazil. Cad Saúde Pública. 2013 Mar; 29(3):609-20.

18. Freitas JG, Cunha GH, Barroso LMM, Galvão MTG. Administration of medications for children born exposed to human immune deficiency virus. Acta Paul Enferm. 2013; 26(1):42-9.
19. Alves KC, Fram DS, Diccini S, Belasco AG, Barbosa DA. Prevalence and risk factors for human immunodeficiency virus infection in pregnant women. Acta Paul Enferm. 2009; 22(3):307-12.

20. Ministério da Saúde (BR). Programa Nacional de DST e Aids. Guia de tratamento clínico da infecção pelo HIV em pediatria. $3^{\text {a }}$ ed. Brasília (DF): MS; 2006.

21. Talisuna-Alamo S, Colebunders R, Ouma J, Sunday P, Ekoru K, Laga M, et al. Socioeconomic support reduces nonretention in a comprehensive, community-based antiretroviral therapy program in Uganda. J Acquir Immune Defic Syndr. 2012 Apr 1; 59(4):e52-9.

22. Galvão MTG, Lima ICV, Cunha GH, Mindêllo MIA. Estratégias de mães com filhos portadores de HIV para conviverem com a doença. Cogitare Enferm. 2013; 18(2):230-7.

23. Silva LMS, Moura MAV, Pereira MLD. The daily life of women after HIV/aids infection: guidelines for nursing care. Texto Contexto Enferm [online]. 2013 [acesso 2014 Mar 01]; 22(2):. Disponível em: http:/ / www.scielo.br/ scielo.php?pid=S010407072013000200009\&script $=$ sci_arttext\&tlng $=$ en

24. Alvarenga WA, Dupas G. Experience of taking care of children exposed to HIV: a trajectory of expectations. Rev Latino-Am Enfermagem. 2014; 22(5):848-56.

25. Liamputtong P, Haritavorn N, Kiatying-Angsulee N. HIV and AIDS, stigma and AIDS support groups: Perspectives from women living with HIV and AIDS in central Thailand. Soc Sci Med. 2009 Sep; 69(6):862-8.

26. Rotheram-Borus MJ, Swendeman D, Lee SJ, Li L, Amani B, Nartey M. Interventions for families affected by HIV. Transl Behav Med. 2011 Jun; 1(2):313-26.

27. Wacharasin C. Families suffering with HIV/AIDS: what family nursing interventions are useful to promote healing? J Family Nurs. 2010; 16(3):302-21. 